\title{
Management of gingival cyst of a newborn: a case report with epidemiological data.
}

\author{
Fathimath Fairoo ${ }^{1}{ }^{\dagger}$, Yaafiya saleem $^{{ }^{\dagger}}$, Md. Ashif Iqbal $^{{ }^{*}}$
}

\section{AFFILIATION:}

1. Fathimath Fairooz ${ }^{\dagger}$

Graduated from Update Dental College, Bangladesh

BM\&DC No: 12543

Address: Fehivillage, HA, Dhidhoo, Maldives

Mail: phaifairooz@gmail.com

Contact no: +9609722989

https://orcid.org/0000-0001-7637-9705

2. Yaafiya Saleem

Graduated from Update Dental College, Bangladesh

BM\&DC No: 12532

Address: Veenus aage, G.Dh fiyoaree, Maldives

Mail:yerphie@gmail.com

Contact no: +9607844092

https://orcid.org/0000-0001-7002-0822

3. Md. Ashif Iqbal*

Associate Professor \& Head

Dept. of Periodontology \& Oral Pathology

Update Dental College, Bangladesh

Mail: drasif100@gmail.com

\section{$(t)$ : These Authors contributed equally to this work}

\section{Article info.}

Received: 17 January 2021

Accepted: 23 February 2021

Volume: Vol-11, Issue-1, April 2021

DOI: https://doi.org/10.3329/updci.v11i1.53005

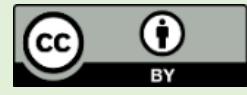

(c) Authors retain copyright and grant the journal right of first publication with the work simultaneously licensed under Creative Commons Attribution License CC - BY 4.0 that allows others to share the work with an acknowledgment of the work's authorship and initial publication in this journal.

https://creativecommons.org/licenses/by/4.0/

Publisher: Update Dental College, Dhaka, Bangladesh

Web: www.updatedentalcollege.edu.bd

E-mail: updcj@hotmail.com

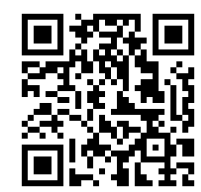

\footnotetext{
Scan QR code to see the latest issue

* Corresponding Author

Md. Ashif Iqbal

Associate Professor \& Head

Dept. of Periodontology \& Oral Pathology

Update Dental College, Bangladesh

Mail: drasif100@gmail.com

https://orcid.org/0000-0002-9490-7927

Cell: +8801716116080
}

\section{ABSTRACT:}

Introduction: Gingival cyst also known as Dental Lamina cyst. They form small nodules or cysts on the alveolar ridge, each up to $2 \mathrm{~mm}$ in diameter. They are considered to be due to proliferation of the epithelial rests of Serres but can arise on the lateral aspects of the ridge and the crest. They are considered to be benign lesions which usually are present on the alveolar ridge and are often mistaken as neonatal tooth.Objective: The aim of this case report is to enlist and describe the diagnostic features and management of the gingival cyst of newborn, as these kind of lesions can cause anxiety and fear among the parents. It is important to diagnose these conditions in order to prevent unnecessary surgical interventions and provide adequate care and proper knowledge to the parents. Method: This is a case study of asymptomatic gingival cyst which was present in a newborn at the time of birth on the lower alveolar ridge. Diagnosis of this keratin filled small cystic lesion was made on the basis of clinical history and oral findings. Conclusion: Gingival cyst of infants are transient lesions. No definitive treatment was given but the patient was kept on follow-up for 3 months during which the lesion regressed by itself.

KEYWORDS: Dental lamina cyst, gingival cyst, newborn cyst, inclusion cyst

\section{INTRODUCTION}

Dental lamina cyst is a true gingival cyst as it is lined by stratified squamous epithelium and occasionally contain inflammatory cells in the connective tissue. It is of minor pathological concern. Microscopic evaluation shows a cystic lumen, filled with desquamated keratin which is responsible for the yellowish coloration of the lesion.(1)

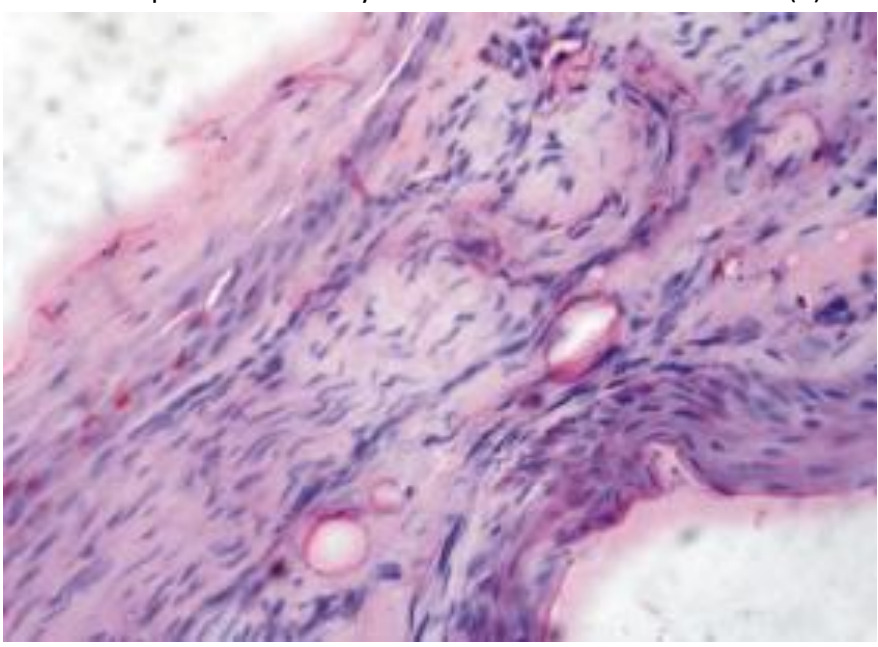

Figure no 1: Cystic lining of dental lamina cyst

Based on histological origin and clinical location, oral cystic lesions in neonates can be classified as (2)

1. Gingival cyst of newborn/ dental lamina cyst

2. Epstein pearl

3. Bohn's nodule

Epstein pearls are cystic, keratin-filled nodules found along the midpalatal raphe, probably derived from entrapment of epithelial remnants along the line of fusion of palatal folds(3) whereas Bohns nodules are keratin filled cysts which appears as numerous nodules along the junction of hard and soft palate. Histologically consisting of 
mucous glands, ducts and clinically seen as, grayish white and are firm in consistency. (4)

According to a study conducted in Mexico based on the Prevalence of oral findings and genetic disorders On 2216 newborns, bohns nodule, Epstein pearl and dental lamina cyst were the most common oral lesions. Prevalence of bohns nodule was the highest, which was 70.0 $\%$, Epstein pearl $65.0 \%$ and dental lamina cyst $44.7 \%$. (5)

Study also was focused based on the site of the dental lamina cyst which demonstrated that the highest incidence of the lesion was seen on the posterior portion of the maxilla, which was recorded as $85.3 \%$ while in mandible it was on the anterior portion being $84.3 \%$.(5) A study conducted in India by George et al(6) on 1038 newborns reveals that gingival cyst of infants was present in $13.8 \%$ neonates, out of which $10.8 \%$ was on the alveolar region, $1.8 \%$ palatally and $1.2 \%$ on both regions. Murat $\mathrm{C}$, etinkaya et al(7)conducted a study on Turkish newborn population to determine intra oral abnormalities, in which $15 \%$ was recorded as gingival cyst(7), whereas Benigno Monteagudo et al (8)reported $13.4 \%$ in Spanish newborns. Benigno Monteagudo stated that higher body weight and female sex had a higher predeliction whereas other authors have reported no significant correlation between gender, body weight, gestation and oral cysts. $(7,9)$ Despite the high prevalence, these cysts are rarely seen by the dentists due to their transient nature. Usually, they disappear within two weeks to 5 months without any treatment.(10)

\section{CASE REPORT}

A healthy child 1 month and 10 days of age reported to update dental college and hospital by her parents complaining of swelling on lower gums. The parents disclosed that they first noticed the swelling since birth and there is no difficulty during feeding. They also showed concern about the gradual increase in size of lesion during this time period. On examination, no noticeable findings were recorded extra orally. the child was full-term born with unremarkable medical and dental history.

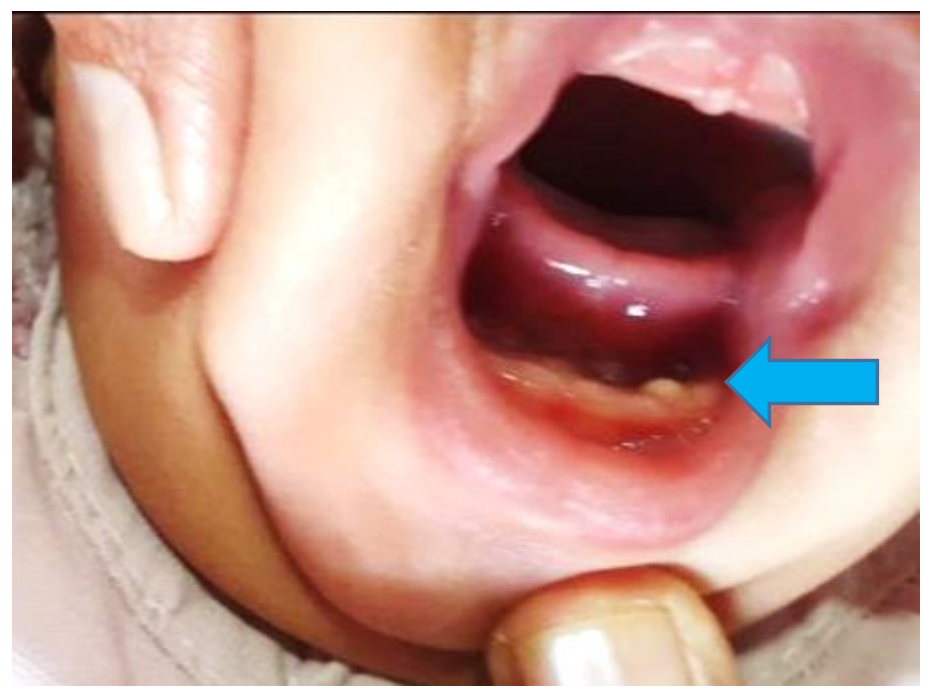

Figure no.1 - showing the lesion

On intraoral examination a small yellowish, single nodule was found on the crest of lower left side of alveolar ridge. It was non tender, soft and fluctuating in consistency. The size of the lesion was approximately $2-2.5 \mathrm{~mm}$. No other abnormality was found on the tongue, palate, mucosa and floor of the mouth. On the basis of clinical examination and appearance of the lesion, the diagnosis of the dental

24| $P$ a g $\mathrm{e}$ lamina cyst was made. The parents were reassured and educated about the transient nature of the cyst and oral hygiene instructions were given. Regular follow up after every month was advised.

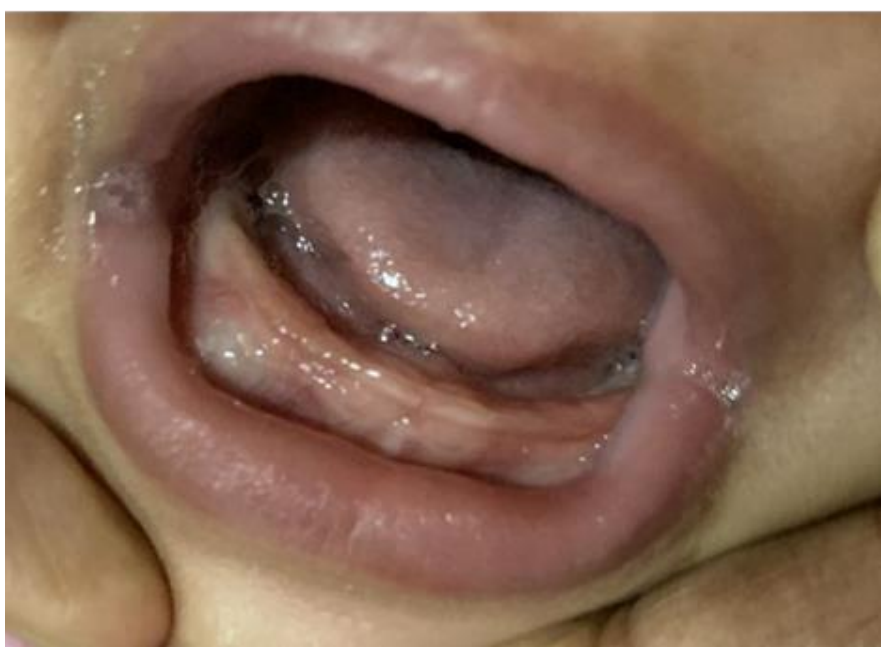

Figure 2: complete regression of the lesion

After 1 month, first follow-up visit was done. the lesion was observed to be same as before and no further change was seen. On the $2^{\text {nd }}$ follow-up visit after 30 days, slight elevation of the lesion and increase in size was noticed. The size was approximately 3-4 mm and same consistency as before. On the following $3^{\text {rd }}$ visit , there was complete regression of the lesion with no defect on the alveolar ridge. Parents revealed that the lesion may have ruptured while using the teething toys. The infant was healthy and the parents were satisfied with the outcome.

\section{DISCUSSION}

Dental lamina cyst which appear as white small, multiple nodules are originated from the cystic degeneration of epithelial rest of serres which are located below the surface epithelium. Rest of serres may be the result of breakage of epithelial pedicle from the surface epithelium during dental organ formation.(2) later, some of the gingival cysts may open onto the surface leaving clefts while others may be involved by the developing teeth. Some degenerate and disappear and the keratin debris are digested by giant cells. However, some remnants of the epithelium may remain in the inactive form throughout the life (9) The cysts occur in children less than 5 months of age. examination of newborn within 3 days may increase frequency of discovering palatal and gingival cysts as these kinds of lesion regress by itself within less than 5 months. (7) Diagnosis of these lesions are done on the basis of history and clinical examination. Histopathological analysis is not essential but needle aspiration biopsy would definitely confirm fluid filled cyst, ruling out solid lesions. Radiographic examination does not play an important role as usually no bone involvement is seen. But it can be taken to evaluate the association of these cysts with natal and neonatal teeth.(11)

As these cysts are transient in nature, suction and deglutition also play an important role in degeneration of the cyst by discharging the cystic content(2).So, the treatment options of these kind of lesions are no treatment and follow-up with close monitoring of these lesions without any therapeutic and invasive procedures. However, if the lesion is associated with natal or neonatal teeth, marsupialization and

Website: https://www.banglajol.info/index.php/UpDCJ 
surgical excision can be carried out if needed. (11)

Roberta Marini1*, Nicolae Chipaila et al (1) reported a symptomatic gingival cyst case where surgical excision was performed on multiple lesions on a 2 month old baby on two separate occasions under local anesthesia to overcome feeding and bleeding problem.

Therefore treatment should be case specific and more emphasis should be given mainly on parent counselling and educating them about the innocuous nature and self-limiting characteristic of these lesions.(12)

\section{CONCLUSION}

Unlike any other lesions gingival cysts of infants can be easily diagnosed based on the clinical appearance and characteristics, which makes it pointless to perform invasive histopathological examination. So, the dentist should have the proper knowledge about these lesions in order to give the correct diagnosis to avoid unnecessary medications and provide proper reassurance to the parents regarding this self-limiting lesion.

PATIENT CONSENT: Author proclaimed that the patient's parents has given consent regarding images to be share for research and journal publication.

LIMITATION OF THE STUDY: As the child was 1 month and 10 days, It was difficult to capture close images.

\section{REFERENCES:}

1. Marini R, Chipaila N, Monaco A, Vitolo D, Sfasciotti GL. Unusual symptomatic inclusion cysts in a newborn: A case report. J Med Case Rep. 2014;8(1):4-7.https://doi.org/10.1186/1752-1947-8-314 PMid:25241967 PMCid:PMC4178315

2. Moda A. Gingival Cyst of Newborn. Int J Clin Pediatr Dent. 2011;4(1):834.https://doi.org/10.5005/ip-journals-10005-1087 PMid:27616865 PMCid:PMC4999644

3. van Heerden WFP, van Zyl AW. Diagnosis and management of oral lesions and conditions in the newborn. South African Fam Pract. 2010;52(6):489-91.https://doi.org/10.1080/20786204.2010.10874032

4. Patil S, Sukumaran A, Majumdar B, Jafer M, Maralingannavar M. Oral Lesions in Neonates. Int J Clin Pediatr Dent. 2016;9(2):131-8. https://doi.org/10.5005/jp-journals-10005-1349

PMid:27365934 PMCid:PMC4921882

5. Perez-Aguirre B, Soto-Barreras U, Loyola-Rodriguez JP, Reyes-Macias JF, Santos-Diaz MA, Loyola-Leyva A, et al. Oral findings and its association with prenatal and perinatal factors in newborns. Korean J Pediatr. 2018;61(9):279-84.https://doi.org/10.3345/kjp.2017.06177 PMid:30274505 PMCid:PMC6172521

6. George D, Bhat SS, Hegde SK. Oral findings in newborn children in and around Mangalore, Karnataka State, India. Med Princ Pract. 2008;17(5):385-9.https://doi.org/10.1159/000141502 PMid:18685278

7. Çetinkaya M, Öz FT, Orhan Al, Orhan K, Karabulut B, Can-Karabulut DC, et al. Prevalence of oral abnormalities in a Turkish newborn population. Int Dent J. 2011;61(2):90-100. https://doi.org/10.1111/i.1875-595X.2011.00020.x PMid:21554278

8. Monteagudo B, Labandeira J, Cabanillas M, Acevedo A, Leõn-Muiños E, Toribio J. Prevalence of milia and palatal and gingival cysts in spanish newborns. Pediatr Dermatol. 2012;29(3):301-5. https://doi.org/10.1111/j.1525-1470.2011.01433.x PMid:21995277
9. Madathil J, Negi B, Kumar N. Gingival cyst of new born: a case report. Int J Contemp Pediatr. 2016;3(3):1129-31. https://doi.org/10.18203/2349-3291.ijcp20162409

10. Paula JDR, Dezan CC, Frossard WTG, Walter LRF, Pinto LMCP. Oral and facial inclusion cysts in newborns. J Clin Pediatr Dent. 2006;31(2):127-9. https://doi.org/10.17796/jcpd.31.2.rw3h853m3rk242q0 PMid:17315809

11. Chauhan D, Chauhan T, Kaundal J, Parasher K, Sharma K, Thakur S Congenital gingival cyst of neonate: Dentist's enigma. SRM J Res Dent Sci. 2013;4(3):135. https://doi.org/10.4103/0976-433X.121643

12. Singh RK, Kumar R, Pandey RK, Singh K. Dental lamina cysts in a newborn infant. BMJ Case Rep. 2012;2-4. https://doi.org/10.1136/bcr-2012-007061 PMid:23048002 PMCid:PMC4544414

To submit your manuscript, Mail us to : updcj@hotmail.com

To see our latest issue, click the following link https://www.banglajol.info/index.php/UpDCJ 